\title{
Exploring the Tensions in Organizational Theories
}

\author{
Emelah, Gentle E. \\ Enyia, Charles Daniel \\ University of Port Harcourt, Nigeria
}

Doi: 10.19044/esj.2018.v14n10p373 URL:http://dx.doi.org/10.19044/esj.2018.v14n10p373

\begin{abstract}
Today's organizations cannot survive through the application of old theories which are considered obsolete. However, some of these 'old theories' still maintain their relevance in the operation of businesses today. The complexity and dynamism of the world have introduced more tensions in organizational theories as some of the theories were introduced with the intention of refuting existing theories. Each new theory had it own assumptions, characteristics and hypothetical beliefs which made them attract relevance when they were first introduced because they were assumed to fill an existing gap. This paper explores some of these theories and maintains that the tensions they create is borne out of the battle for superiority when non can actually solve all organizational problems
\end{abstract}

Keywords: Organizations, Theories, relevance, assumptions, complex, dynamic

\section{Introduction}

Organizations can be referred to as goal-directed entities which are structured deliberately and coordinated in such a way that it connects with external environment (Daft \& Armstrong, 2007). Aldrich (1979) defined organization as goal-directed, boundary maintaining and socially constituted systems which consists of human activities. From this definition, we can deduce three fundamental dimensions which are; goal oriented boundary maintaining and activity system. As a goal directed system, every organization is a purposive system whereby every member behaves as if there is a goal to be achieved and they work towards such objectives. As a boundary maintaining system, every organizational member can be easily differentiated from non-organizational members, likewise its activities. Thirdly, as an activity system, every organization has its processes of accomplishing work ranging from processing of raw material, people or information. According to 
Liu (2007), organizations are combination of mental activities of members who have same goals.

Organizational theory on the other hand is derived from these activities and practices which occur in organizations. It is the study of the function, structure and design of organization (Zhao \& Zhang, 2013). Tompkins (2005) is of the opinion that organizational theory is the study of why and how organizations behave the way they do. In other words, organizational theory covers the history, development and thoughts which describe activities going on in organizations. The tension in organizational theory can be deduced from its historical perspective to its current state. According to Scott \& Davis, the study of organizations emerged in the 1940s and it has roots which span the existence of humans. Pre-historical clans built stone and dirt monoliths just like Stonehenge and the Mississippi mounds. In 3500B.C, the Egyptians could organize actions of people to build cities and societies. In these early days, workers were able to organize guilds in Rome, Greece and Egypt. The early years also witnessed the Chinese ability to produce over 125,000 tons of iron annually (Mcschane \& Von Glinow, 2005). Sun Tzu in 500 BC had also provided means and strategies for conquering and controlling population. They made the world believe that there is a process of planning and organizing before every battle can be won. In the $16^{\text {th }}$ century, Nicolo Machiavelli (1505), proposed how a prime can control his area of jurisdiction. Plato and Aristotle in the $3^{\text {rd }}$ century had also written about persuasive communication towards business and society. However, the late $18^{\text {th }}$ century witnessed the advocacy of Adam Smith towards division of labor in organization. Karl Marx also proposed the workers' paradise strategy as a means to increasing industrialization in western societies. These could be referred to as the ancient history of organizational theories.

However, these historical perspectives was replaced with the classical foundation which also gave birth to scientific management theory by Frederick Taylor, Bureaucratic theory by Max Weber as well as Administrative theory in Henry Fayol. The scientific management tried to maximize efficiency in organization through specialization and standardization. It made use of time and motion studies. Bureaucratic theory is governed by top-down rules and regulations where employees work on strictly defined responsibility to restrained powers.

Administration theory was more focused on the principles of management as well as the five basic elements of management which are planning, organizing, commanding, coordination and control.

The Neo-classical organizational theory led to other theories which began to consider human as resources rather than being assets. This theory was led by Max Weber and his team who conducted Hawthorne studies in the 
1920s. Other motivational theories like theory of needs, two-factor theory, ERG theory, etc were also formed in support of human resources.

The contemporary theories have further given birth to several other theories such as the systems theory which believes that all organizations consist of three parts: components, linking process and goal (Bakke, 1959). The contingency theory which was also proposed by Lauren \& Lorsch suggested that there is no best theory to direct any enterprise. This is one of the greatest tensions of organizational theories because every theory seems to be right in its own eye but not in all environment (Enyia, 2015). This tension has led to multiples theories which have made the study of organization complex and dynamic in nature.

\section{THE MODERNIST AND SYMBOLIC INTERPRETATIVE PERSPECTIVES IN ANALYSIS ORGANIZATIONAL THEORY TENSIONS}

The tensions in organizational theory can be further explained with the analyses of the modernist and symbolic interpretative perspective. According to Hatch (2006) in a summary of the tensions arising from these two perspectives of management, he was of the opinion that modernism believed that organizational theory is gained through the five senses and this can be confirmed through a replication of procedures while the symbolic interpretation perspective believe that these knowledge gained through the five senses cannot be replicated by others. Secondly, the modernist believe that truth is discovered through valid conceptualization and reliable instrument which allows testing of knowledge against an objective while symbolic interpretation believe in interpretivism which states that all knowledge is relative to the knower and can only be understood from the point of view of those involved. Thirdly, modernism perspective believe that when entities operating in a real world is well managed, their decision and actions are driven by norms of rationality, effectiveness and efficiency while symbolic interpretation perspective believes that organizations are continually constructed and re-constructed by members through symbolically mediated interaction. This means that organizations are socially constructed entities. Fourthly, modernism believes that organizations are always in search of universal laws, methods and techniques which favors rational structures, rules, procedures and practices. While symbolic interpretative perspective describes how people give meaning and order to their expression with specific context through symbolic and interpretative acts, forms and processes.

With the introduction of information and communication technology, there has been an increase on the tensions in organizational theory development and implementation because it also requires special skills to work with computer based systems. Today, data can be analyzed with the click 
of the button which is quite different from the days when Abacus and mainframe computer were used. The environment we have found ourselves today has also increased the tensions in organizational theories because even the contemporary theories are getting obsolete, hence, the need for more current theories.

\section{Conclusion}

Organizational theories have developed from pre-scientific to contemporary era and all these stages have introduced validity as at the point when these theories were propounded. This study have considered the existence of theories as early as the $3500 \mathrm{BC}$ which is against the proposed belief that theories of organizations emerged in the earlier $20^{\text {th }}$ century. The classical era criticized the pre-scientific era because pioneers like Frederick Taylor believed in time and motion studies as a means of achieving efficiency and effectiveness. The story goes on and on as new theories tried to fill in the gaps created by previous theories. Today, these gaps still exist in more complex and dynamic manner which requires current theories to be established. 


\section{References:}

1. Aldrich, H. (1979). Organizations and Environments. Englewood Cliffs, NJ: Prentice-Hall.

2. Bakke W.E. (1959). Concept of the social organization. In: Modern organization theory (Haire M, ed). USA: Chapman and Hall.

3. Daft R.L, Armstrong A. (2007). Organizational Theory and Design. . USA: Graphic World Inc.

4. Enyia C. D. (2015). A Review of the evolution of Management schools of thought. Proceedings of the second conference on Human Capital Development 2(2) (pp. 150-160). Port Harcourt: Fortress Educational and consultancy services limited.

5. Hatch, M. J. (2006). Organization Theory: Modern, Symbolic and Postmodern Perspectives . Oxford: University Press.

6. Liu Y. (2007). Multidimensional Perspective of Organizational Theory. Beijing: Tsinghua UniversityPress.

7. Liu, S.-H. (1998). Understanding Confucian Philosophy. Westport, CT: Praeger.

8. Machiavelli. N. (1532). The Prince. Italy: Antonio Blado d'Asola.

9. McShane, S.L \& Von Glinow M.A. (2005). Organizational Behavior . New York, NY: McGraw-Hill/Irwin.

10. Scott. W. R. and Davis, G. F. (2007). Organizations and Organizing: Rational, Natural, and Open System Perspectives. Upper Saddle River NJ.: Pearson Prentice Hall.

11. Sun Tzu. (1910). Art of War. England: Allandale Online Publishing.

12. Tompkins J.R. (2005). Organizational Theory and Public Management. . USA: Clark Baxter Press.

13. Zhao Y \& Zhang W.J. (2013). Organizational theory: With its applications in biology and ecology. 2International Academy of Ecology and Environmental Sciences, Hong Kong Network Biology $3(1), 45-53$. 